\title{
Formative (Classroom) Assessment Techniques
}

\author{
Igor Marks *
}

\begin{abstract}
The author presents formative (classroom) assessment techniques with the purpose of improving the teaching process and the learner's development. At the same time, the paper emphasizes the importance of feedback in the teaching process.

Key words: formative assessment, formative (classroom) assessment techniques, feedback, learner-centred teaching.
\end{abstract}

A good teacher should use both, summative as well as formative assessment during his/her work. Summative assessment usually includes the assessment of what learners have learned during a specific period of time. It has a formal character and it sums up partial assessments into a summary, final assessment. Most often it takes the form of an official classroom grading. When summative assessment prevails in a teacher's work, it may happen that during the final examination, or testing, etc., the teacher finds out that the learners have understood the topic of instruction in a completely different way than he/she had expected. We can prevent this by using formative (continuous) assessment that focuses on learners' needs. Information obtained in such a way helps the teacher to plan and further improve his/her instruction. Not only does the teacher assess the learners' progress, he/she also assesses the state of his/her own teaching. Thus, the information provided by the assessment is intended not only for the teacher but also for the learner. The teacher informs the learner on the level of his/her development and at the same time, such information has an incentive effect for the learner (Kompolt, 2010, p. 158).

This kind of assessment, according to Gavora (2010, p. 16), corresponds with the current trends in learners' assessment. The assessment model focused on learner's errors has been being abandoned and the attention has been shifting to the facilitation and the development of the learner. At the same time, a thesis has been postulated to make the learner an active subject of assessment. The learner should act not only as the person being assessed but also as the one doing the assessment. Learners should observe, examine and evaluate their own activity and behaviour. Their self-reflection shall be facilitated, which should lead to a realistic self-image. This is so-called autonomous assessment (Slavík, 1999, pp. 133-139).

\footnotetext{
* Igor Marks, Dubnica Institute of Technology in Dubnica nad Váhom, Dubnica nad Váhom, Slovakia; marks@dti.sk
} 
Assessment techniques used by teachers directly in the classroom during classroom instruction have several advantages (Angelo and Cross, 1993, pp. 47):

1. They are of a formative nature: unlike final or major exams, they provide feedback on learners' learning.

2. They are speedy: often, they consume just a few minutes of classroom time to administer, and can be processed easily and quickly.

3. They are flexible: they can be tailored to meet the unique and specific concerns and needs of the instructor.

4. They are anonymous for learners (although they need not be): the aim of classroom assessment is not necessarily the need to grade the learners' work or to provide individual learners with feedback on their performance; the aim may be to provide feedback on learners' learning. Anonymity may ensure that students feel free to express not only what they do understand but also what they do not understand.

5. They have a positive impact on the learning process itself; on developing writing skills, critical thinking and on increasing learner motivation.

Teachers and learners need effective ways of monitoring learning throughout the school year. Although individual teachers often develop, discover or simply come across a strategy that works, these informal discoveries rarely come to public attention. Data from similar activities taking place at schools are extremely important for improving teaching as well as learning. They show learners how to learn and study; they encourage teachers to analyse objectively what was going on in the classroom; and they encourage learners to do selfassessment and assess their own learning process.

We used the formative assessment techniques listed below while teaching at university. In various modified forms, they are also used at primary and secondary schools.

Formative assessment provides information that can be used for the purpose of improving the content of the course as well as for improving the teaching methods and, ultimately, the learners' learning. Formative assessment is most effective when administered often. Efficiency is ensured when the information identified is evaluated immediately and the results are applied directly in the next lesson.

In case of frequent use of formative assessment techniques, they can have the following impacts (Haugen, 1999):

For the school and for the teacher, formative assessment techniques can:

- provide day-to-day feedback that can be applied immediately;

- provide useful feedback on what students have learned without loss of time required for preparing tests, oral examination;

- allow to address learner misconceptions or lack of understanding in a timely way; 
- play a part in fostering good working relations with learners and encourage them to understand that teaching and learning are on-going processes that require full participation.

For learners, formative assessment techniques can:

- help develop self-assessment and learning management skills;

- reduce feelings of isolation and impotence;

- increase understanding and ability to think critically about the course;

- ensure long-term retention of information acquired.

There are a number of formative assessment techniques. Angelo and Cross (1993, pp. 115-361) list 50 of these techniques. The authors recommend that teachers interested in using these techniques begin with the following ones:

"The One-Minute Paper" (also called the Minute Paper and Half-Sheet response)

The teacher asks students two or three minutes before the end of the lesson to respond briefly in writing to one of the following two questions: "What was the most important thing you learned today? and "What important questions have remained unanswered to you?". Alternatively, the teacher can provide the learner with an unfinished declarative sentence: "For me, the most important thing I learned today is ..."; "In today's lesson I did not quite understand ..." (Enerson, Plank and Johnson, 2007, p. 5).

This technique allows for the assessment of the match between instructional goals and learners' perceptions of these goals and their own learning. It can be used in classes where, on a regular basis, learners operate with large amounts of new, basic information used for introduction to a given topic, etc.

\section{"The Muddiest Point"}

The teacher asks learners to jot down a brief and quick response to the following question: "What was the muddiest point for you in today's lesson, the homework assignment, reading, the film, etc.?"

This technique provides speedy feedback on what learners find the least clear or the most confusing. This information can help teachers to decide what to emphasize more in the future and how much time to spend on a given topic or question. Learners must also quickly decide and determine what they do not understand and be able to articulate their confusion. It is recommended to use this technique at the end of a class, lesson, thematic unit, assignment, etc.

\section{"The One-Sentence Summary “}

The teacher asks learners to summarize the topics and questions discussed in one or two sentences. The teacher can gauge the extent to which learners can summarize a large amount of information (concisely, completely and accurately). Learners should follow rules of sentence construction and they must 
think creatively about the content learned. Learners acquire the ability to condense information that thus those can be later easily processed and recalled.

\section{"Directed Paraphrasing “}

The teacher asks learners to paraphrase part of a lesson, or to paraphrase it for a specific (fictitious) audience or purpose, using their own words. This technique allows for the examination of learners' understanding of information and their ability to transform it into such a meaningful form so that it can be understood by specific audiences other than the learner and the teacher. This technique is much more complex than simple paraphrasing (or summary) in that the school teaches the learner to speak or write for a particular purpose and to a particular audience.

\section{"Application Cards “}

After a particular question has been introduced to learners, the teacher passes out index cards and asks learners to write down at least one possible, real-world application for the material they have just been dealing with. This technique allows for a quick determination whether learners understand what they have learned. Moreover, learners are forced to link new information with prior knowledge.

The techniques outlined above look to be simple at first glance. However, their problem is that due to lack of time during classroom instruction, they are not used at all. Thus, teachers lack data or material that can provide feedback when assessing the lesson. Hence, teachers constantly make the same mistakes and teach in the same, established way.

There are no limits set for designing our own formative assessment techniques. However, teachers should bear in mind such techniques need to be simple. They must answer the following simple questions for themselves: "What do I want my students to learn?"; "What kind of answers will I get?", and alike. Teachers must try to gather only information that is relevant for them in the particular moment and that they, as teachers, want to process, evaluate and use in the future. At the same time, learners need to know why the teacher uses a particular technique. A true and sensible explanation of the technique and of its purpose can have a good impact on further lesson planning.

After information from learners have been gathered, it is essential to analyse it, sort the answers into several main categories, and most important, not to miss anything important. Teachers may help themselves with the following questions: "What kinds of answers appear most often?"; "What have I not known about my learners yet?"; "How do I plan to use the information obtained?" (Enerson, Plank and Johnson, 2007, pp. 1-2). Furthermore, one should not be afraid to inform the learners about some of the data analysed. With learners, the obtained 
information can serve as a tool for improving their learning skills (Nicola, Macfarlane and Dickb, 2006, pp. 208-210).

One of the ways of improving education is to improve teaching. Formative assessment techniques can help us to do so. Their advantage is that they do not require specialised professional training as they can be administered by all teachers, at all levels and types of schools, and by teachers with different teaching licences.

\section{References}

ANGELO, T. A. and CROSS, K. P. Classroom Assessment Techniques. San Francisco: Jossey Bass Publishers, 1993.

ENERSON, D. M., PLANK, K. M. and JOHNSON, R. N. An Introduction to Classroom Assessment Techniques [online]. [viewed 17 November 2013]. Available from:

$<\mathrm{http} / / / \mathrm{www}$. schreyerinstitute.psu.edu/pdf/classroom_assessment_techniques_in tro.pdf $>$

GAVORA, P. Akí sú moji žiaci? Pedagogická diagnostika žiaka. Nitra: Enigma Publishing s.r.o., 2010.

HAUGEN, L. Classroom Assessment Techniques (CATs) [online]. 1999 [viewed 2 December 2013]. Available from:

<http://www.celt.iastate.edu/teaching/cat.html>

KOMPOLT, P. Pedagogická diagnostika a akčný výskum. Bratislava: Univerzita Komenského v Bratislave, 2010.

NICOLA, D. J. and MACFARLANE-DICKB, D. Formative assessment and selfregulated learning: a model and seven principles of good feedback practice. Studies in Higher Education, Vol. 31, 2006, No. 2, 199-218.

SLÁVIK, J. Hodnocení v současné škole. Praha: Portál, 1999. 